Research, Society and Development, v. 9, n. 11, e88491110742, 2020

(CC BY 4.0) | ISSN 2525-3409 | DOI: http://dx.doi.org/10.33448/rsd-v9i11.10742

Years of potential life lost in HIV/AIDS patients and its determinant factor Anos potenciais de vida perdidos com HIV/AIDS pacientes e seu fator determinante Años potenciales de vida perdidos en el VIH / SIDA pacientes y su factor determinante

Received: 11/30/2020 | Reviewed: 11/30/2020 | Accept: 12/02/2020 | Published: 12/05/2020

\title{
Radian Ilmaskal
}

ORCID: http://orcid.org/0000-0002-6396-3432 Department of Public Health, STIKes Alifah Padang, Indonesia E-mail: radian.ilmaskal@gmail.com

Gusni Rahma

ORCID: https://orcid.org/ 0000-0002-6616-1670 Department of Public Health, STIKes Alifah Padang, Indonesia E-mail: gusnirahma@gmail.com

Edo Gusdiansyah ORCID: https://orcid.org/0000-0002-1254-8706 Department of Nursing, STIKes Alifah Padang, Indonesia E-mail: edo.gusdiansyah@gmail.com

\begin{abstract}
Padang is one of the areas in West Sumatera with the highest HIV/AIDS cases. There are 370 HIV cases and 39 AIDS cases in 2017. These cases increased in 2018 to 447 cases for HIV and 103 cases for AIDS. This study aimed to find out the description of HIV/AIDS patients who have been passed away due to socio-demography characteristics. Also to know the number of Years of Potential Life Lost (YPLL) caused by HIV/AIDS infection and its determinant factors. This study used a quantitative methodology with retrospective cohort study design and collected the data from medical records installation in RSUP Dr. M. Djamil Padang on patients with HIV/AIDS diagnosis that have been passed away. The data then analyzed using independent t-test, one-way ANOVA, and multiple linear regression. The result showed that 186 of death cases happened on 2015-2020 were mostly dominated by man $(76.34 \%)$ with the average age around 31 years old, married $(65.59 \%)$, and infected through heterosexual relationship (29.03\%). The average year of YPLL was 26.09 year. Moreover, this study found that there was a significant relation between ARV therapy (CI 95\% P=0.002) and the total of CD4 diagnosed with YPLL (CI 95\% P=0.0001). Therefore, respondents of
\end{abstract}


productive age should get serious attention from the Government and society around. Also for the Health Office and AIDS prevention commission were expected to make innovations in preventive promotive efforts and strengthening surveillance system on HIV/AIDS either to the risky group or general society.

Keywords: Years of potential life lost; HIV-AIDS; Padang.

\section{Resumo}

Padang é uma das áreas em West Sumatera com o maior número de casos de HIV / AIDS. Há 370 casos de HIV e 39 casos de AIDS em 2017. Esses casos aumentaram em 2018 para 447 casos de HIV e 103 casos de AIDS. Este estudo teve como objetivo conhecer a descrição de pacientes com HIV / AIDS que faleceram por características sociodemográficas. Também saber o número de Anos de Vida Potencial Perdidos (YPLL) causados pela infecção pelo HIV / AIDS e seus fatores determinantes. Este estudo utilizou uma metodologia quantitativa com desenho de estudo de coorte retrospectivo e coletou os dados da instalação de prontuários médicos no RSUP Dr. M. Djamil Padang de pacientes com diagnóstico de HIV / AIDS que já faleceram. Os dados foram então analisados usando teste $t$ independente, ANOVA unilateral e regressão linear múltipla. O resultado mostrou que 186 dos casos de óbitos ocorridos em 2015-2020 foram em sua maioria dominados por homens (76,34\%) com média de idade em torno de 31 anos, casados $(65,59 \%)$ e infectados por relacionamento heterossexual $(29,03 \%)$. O ano médio de YPLL foi de 26,09 anos. Além disso, este estudo constatou que houve uma relação significativa entre a terapia ARV (IC 95\% P =0,002) e o total de CD4 com diagnóstico de LPVP (IC 95\% P = 0,0001). Portanto, os entrevistados em idade produtiva devem receber atenção séria do Governo e da sociedade ao redor. Esperava-se também que o Gabinete de Saúde e a comissão de prevenção da AIDS fizessem inovações nos esforços de promoção preventiva e no fortalecimento do sistema de vigilância do HIV / AIDS para o grupo de risco ou para a sociedade em geral.

Palavras-chave: Anos de vida potencial perdidos; HIV-AIDS; Padang.

\section{Resumen}

Padang es una de las zonas de Sumatera occidental con el mayor número de casos de VIH / SIDA. Hay 370 casos de VIH y 39 casos de SIDA en 2017. Estos casos aumentaron en 2018 a 447 casos de VIH y 103 casos de SIDA. Este estudio tuvo como objetivo conocer la descripción de los pacientes con VIH / SIDA fallecidos por características sociodemográficas. También conocer el número de Años de Vida Potencial Perdidos (AVPP) provocados por la 
infección por VIH / SIDA y sus factores determinantes. Este estudio utilizó una metodología cuantitativa con diseño de estudio de cohorte retrospectivo y recopiló los datos de la instalación de registros médicos en RSUP Dr. M. Djamil Padang sobre pacientes con diagnóstico de VIH / SIDA que han fallecido. Luego, los datos se analizaron utilizando una prueba $\mathrm{t}$ independiente, ANOVA de una vía y regresión lineal múltiple. El resultado mostró que 186 de los casos de muerte ocurridos en 2015-2020 fueron dominados en su mayoría por hombres $(76,34 \%)$ con una edad promedio de alrededor de 31 años, casados $(65,59 \%)$ e infectados a través de una relación heterosexual (29,03\%). El año promedio de APVP fue de 26,09 años. Además, este estudio encontró que había una relación significativa entre la terapia ARV (IC 95\% P = 0,002) y el total de CD4 diagnosticados con APVP (IC 95\% P = 0,0001). Por lo tanto, los encuestados en edad productiva deben recibir una atención seria del gobierno y la sociedad que los rodea. También se esperaba que la Oficina de Salud y la comisión de prevención del SIDA hicieran innovaciones en los esfuerzos de promoción preventiva y fortalecimiento del sistema de vigilancia del VIH / SIDA, ya sea para el grupo de riesgo o la sociedad en general.

Palabras clave: Años de vida potencial perdidos; VIH-SIDA; Padang.

\section{Introduction}

The problem of HIV/AIDS (Human Immunodeficiency Virus/ Acquired Immune Deficiency) is still becoming a challenge in health in almost all part of the world. In 2019, there was 38 million souls lived with HIV/AIDS and 690.000 souls died because of AIDS and other related diseases. Moreover, 7.1 million souls did not know about their HIV status (UNAIDS, 2020). The epidemic of HIV/AIDS also becomes the problem in Indonesia and placed on rank 5 as the country with higher risk of HIV/AIDS in Asia (Kementerian Kesehatan RI, 2017). This case happened in almost all Indonesia provinces especially in higher risk sub population. From the first discovery until June, 2018, HIV/AIDS has been reported of its existence by 433 people (84.2\%) from 514 cities in 34 provinces in Indonesia.

In West Sumatera, the case of HIV/AIDS is keep growing till March 2017 with reported cases of HIV for 1.935 and AIDS for 1.371. West Sumatera occupied in $17^{\text {th }}$ position for province with higher AIDS case rate until March 2017 for about 21.94/100.000 people. This number was still under the national AIDS case rate for 28.45/100.000 people and lower than the previous case rate in 2016 (24.59/100.000 people) (Kementerian Kesehatan RI, 2017). The highest case of HIV/AIDS in West Sumatera was found in Padang with total 
cumulative on 2016 for 1.076 HIV cases and 575 AIDS cases with case rate reported for 56.96/100.000 people. In 2017, the HIV cases had reached 370 cases and 93 AIDS cases and increased in 2018 to be 447 cases in HIV and 103 cases in AIDS (Dinas Kesehatan Kota Padang, 2019).

HIV/AIDS is one of the diseases that affect many teenagers with age range from 20-29 years with short time duration between diagnosis years and dead that is around 4 years. Thus, the opportunity for premature death or death before reached the certain age is even greater. One of the indicators that often used to describe the impact from premature death on health status is Years of Potential Life Lost (YPLL). YPLL refers to the estimation of the average years a person would live if not died prematurely (Gardner \& Sanborn, 1990).

Some previous studies are mostly focused in evaluating the life endurance during a certain period and chance of the death of HIV/AIDS patients. Not many, can describe the total of YPLL or potential year that lost due to HIV/AIDS infection. It is important to recognize the Nation health status, material to evaluate the loss that bear with Nation (including the loss of workers in productive age), plan on health promotion policy for society in younger age. These indicators can be used to value the life expectancy after diagnosed with certain disease. YPLL also useful to evaluate the main cause of death in younger age group (Mc Donnell, Vossberg, Hopkins, \& Mittan, 1998; Rumisha, George, Bwana, \& Mboera, 2020). It also important to compare the relative impact from various diseases to track the difference in spatiotemporal trend and to give framework to evaluate the cost efficiency from intervention (Murray et al., 2002).

Therefore, this study has objective to know the description of HIV/AIDS patients that have been died based on socio-demography characteristic, to know the total of YPLL due to HIV/AIDS infection and its determinant factor in RSUP Dr. M. Djamil Padang.

\section{Methodology}

This study used quantitative methodology with observational research type and retrospective cohort study design. Sugiyono defines quantitative as research method which data was in the form of numbers and statistical analysis (Sugiyono, 2010). The data were obtained from medical records installation in RSUP Dr. M. Djamil Padang which collected around January - July, 2020. 
Research, Society and Development, v. 9, n. 11, e88491110742, 2020

(CC BY 4.0) | ISSN 2525-3409 | DOI: http://dx.doi.org/10.33448/rsd-v9i11.10742

The population of the study was all patients in RSUP Dr. M. Djamil Padang, while the sample was taken from the HIV/AIDS patients who noted as death since 2015 - 2020 for about 186 people.

There were 2 variables used in this study; (a) independent variable which consisted of age at diagnosis, gender, risk of transmission factor, status of ARV (Anti-Retroviral) therapy, and total of CD4 when diagnosed and (b) dependent variable such as, YPLL (Years of Potential Life Lost).

The cut-off point used to count patient's YPLL was 65 years. The data were analyzed using independent t-test, one way ANOVA and multiple linear regression.

\section{Result}

Description of socio-demography characteristic of the research subject can be seen in Table 1 below:

Table 1. Subject Frequency Distribution based on Socio-demography Characteristic.

\begin{tabular}{lcc}
\hline \multicolumn{1}{c}{ Variable } & $\begin{array}{c}\text { Total } \\
(\mathbf{n = 1 8 6})\end{array}$ & $\begin{array}{c}\text { Percentage } \\
(\boldsymbol{\%})\end{array}$ \\
\hline $\begin{array}{l}\text { Age at diagnosis } \\
\text { (mean } \pm \text { SD) }\end{array}$ & $30.74 \pm 8.90$ \\
\hline Gender & & \\
\hline Male & 142 & $76.34 \%$ \\
\hline Female & 44 & $23.66 \%$ \\
\hline Occupation & & \\
\hline Civil Servant & 3 & $1.61 \%$ \\
\hline Indonesian National Military/Police & 2 & $1.08 \%$ \\
\hline Medical Personnel & 3 & $1.61 \%$ \\
\hline Entrepreneur & 60 & $32.26 \%$ \\
\hline Housewife & 19 & $10.22 \%$ \\
\hline Labor & 40 & $21.51 \%$ \\
\hline Student & 8 & $4.30 \%$ \\
\hline No Occupation & 51 & $27.42 \%$ \\
\hline Educational Background & & \\
\hline Never been in School & 3 & $1.61 \%$ \\
\hline Elementary School & 15 & $8.06 \%$ \\
\hline Junior High School & 22 & $11.83 \%$ \\
\hline Senior High School & 89 & $47.85 \%$ \\
\hline University & 57 & $30.65 \%$ \\
\hline Marital Status & & \\
\hline Single & 33 & $17.74 \%$ \\
\hline Married & 122 & $65.59 \%$ \\
\hline Divorced & 31 & $16.67 \%$ \\
\hline Domicile & & \\
\hline Padang & 94 & $50.54 \%$ \\
\hline Padang Pariaman & 35 & $18.82 \%$ \\
\hline Solok & 57 & $20.65 \%$ \\
\hline$\quad$ & \\
\hline
\end{tabular}

Source: Own Study. 
Based on Table 1, the average age at diagnosis was 30.74 year which dominated by male subject for $76.34 \%$. Around $32.26 \%$ worked as entrepreneur and almost half of them (47.85\%) had last education in High School.

The proportion of married subject was more $(65.59 \%)$ than those who single or divorced and if it based on domicile, half of the subject (50.54\%) came from Padang.

Meanwhile, to know the subject characteristic on behavior (risk factor, transmittal and ARV therapy status) and clinical condition (anemia status, total of CD4, opportunistic infection and clinical stadium) can be seen in Table 2 below:

Table 2. Subject Frequency Distribution based on Behavior and Clinical Condition.

\begin{tabular}{lcc}
\hline \multicolumn{1}{c}{ Variable } & Total & $\begin{array}{c}\text { Percentage } \\
(\mathbf{\%}) \mathbf{1 8 6})\end{array}$ \\
\hline Risk of Transmission Factor & & \\
IDU (Injecting Drug User) & 23 & $12.37 \%$ \\
Heterosexual & 54 & $29.03 \%$ \\
Homosexual & 29 & $15.59 \%$ \\
Perinatal & 5 & $2.69 \%$ \\
Transmitted from husband/wife & 40 & $21.51 \%$ \\
Have >1 risk factor & 35 & $18.82 \%$ \\
\hline Status of ARV Therapy & & \\
No & 116 & $62.37 \%$ \\
Yes & 70 & $37.63 \%$ \\
\hline Status of Anemia when Diagnosed & & \\
No Anemia & 50 & $26.88 \%$ \\
Anemia & 136 & $73.12 \%$ \\
\hline Total of CD4 when Diagnosed (cell/mm3) & & \\
$\quad$ 50 & 63 & $33.87 \%$ \\
50 - 200 & 53 & $28.49 \%$ \\
$>$ 200 & 70 & $37.63 \%$ \\
\hline Opportunistic Infection when Diagnosed & & \\
No & 80 & $43.01 \%$ \\
Yes & 106 & $56.99 \%$ \\
\hline Clinical Stadium when Diagnosed & & \\
I & 133 & $71.51 \%$ \\
II & 33 & $17.74 \%$ \\
III & 11 & $5.91 \%$ \\
IV & 9 & $4.84 \%$ \\
\hline
\end{tabular}

Source: Own Study.

In Table 2 above, it is seen that $87.63 \%$ of the subject was infected the HIV virus from non-IDU source. More than a half of the subject was never take ARV therapy $(62.37 \%)$. $73.12 \%$ had anemia and $56.99 \%$ had opportunistic infection while diagnosed.

Only a few (37.63\%) who had the total of CD4 for more than 200 cell $/ \mathrm{mm}^{3}$ and $71.51 \%$ was at Stadium I. Furthermore, to know the description of YPLL due to HIV/AIDS in RSUP Dr. M. Djamil Padang can be seen in Table 3 below: 
Table 3. YPPL Description due to HIV/AIDS Infection in RSUP Dr. M. Djamil Padang.

\begin{tabular}{rccc}
\hline Variable & Mean & Min-Max & SD \\
\hline Years of Potential Life Lost & 26.09 & $2-61$ & 9.86 \\
\hline
\end{tabular}

Source: Own Study.

Table 3 above showed the average potential years that gone due to the HIV/AIDS infection was 26.09 years. While the minimum YPLL was 2 years and the maximum years was 61 with standard deviation 9.86.

Factors that Connected with YPLL

a. Bivariate Analysis

The factors that connected with YPLL are seen in the following Table 4:

Table 4. Factors that Connected with YPLL.

\begin{tabular}{|c|c|c|c|c|}
\hline Variable & $\begin{array}{l}\text { Total of } \\
\text { Deaths }\end{array}$ & $\begin{array}{l}\text { The Average } \\
\text { of YPLL }\end{array}$ & $\begin{array}{l}\text { Standard } \\
\text { Deviation }\end{array}$ & $P$-value \\
\hline \multicolumn{5}{|l|}{ Gender } \\
\hline Male & 142 & 25.96 & 7.91 & \multirow{2}{*}{0.301} \\
\hline Female & 44 & 26.48 & 10.41 & \\
\hline \multicolumn{5}{|l|}{ Marital Status } \\
\hline Divorced & 31 & 29.74 & 8.80 & \multirow{3}{*}{0.047} \\
\hline Married & 122 & 25.76 & 9.09 & \\
\hline Single & 33 & 23.85 & 12.78 & \\
\hline \multicolumn{5}{|c|}{ Risk of Transmission Factor } \\
\hline IDU & 23 & 27.70 & 8.07 & \multirow{2}{*}{0.404} \\
\hline Non IDU & 163 & 26.86 & 10.08 & \\
\hline \multicolumn{5}{|c|}{ Status of ARV Therapy } \\
\hline No & 116 & 27.78 & 10.05 & \multirow{2}{*}{0.002} \\
\hline Yes & 70 & 23.29 & 9.91 & \\
\hline \multicolumn{5}{|l|}{ Status of Anemia } \\
\hline Severe & 26 & 27.77 & 5.52 & \multirow{4}{*}{0.154} \\
\hline Medium & 45 & 27.07 & 8.65 & \\
\hline Mild & 65 & 26.8 & 8.00 & \\
\hline No Anemia & 50 & 23.4 & 23.78 & \\
\hline \multicolumn{5}{|c|}{ Total of CD4 (cell/mm3) } \\
\hline$<50$ & 63 & 30.73 & 9.65 & \multirow{3}{*}{0.0001} \\
\hline $50-200$ & 53 & 26.60 & 8.30 & \\
\hline$>200$ & 70 & 21.51 & 9.16 & \\
\hline
\end{tabular}




\section{Clinical Stadium}

Severe

Mild

166

30.30

14.69

$20 \quad 25.58$

9.036

0.043

Source: Own Study.

The Table 4 above indicated that there were 4 variables that connected to YPLL statistically; marital status ( $\mathrm{p}=0.047)$, ARV therapy status $(\mathrm{p}=0.002)$, total of CD4 ( $\mathrm{p}=0.0001)$ and Clinical Stadium $(\mathrm{p}=0.043)$.

b. Multivariate Analysis

To find out the dominant factor that influence YPLL, multivariate analysis using multiple linear regression test among variables is used. These 5 variables are put into multivariate analysis because they have $\mathrm{p}$-value $<0.25$ on bivariate analysis. The result from multivariate analysis is showed in Table 5 below:

Table 5. Multivariate Analysis on Factors that Connected to YPLL.

\begin{tabular}{clccc}
\hline Model & \multicolumn{1}{c}{ Variable } & OR (Exp $\beta)$ & 95\% CI & P-value \\
\hline Early Model & Marital Status & 1 & & \\
& Single & 0.851 & $0.369-1.965$ & 0.760 \\
& Married & 1.628 & $0.540-4.905$ & 0.387 \\
& Divorced & 2.152 & $1.111-4.169$ & 0.023 \\
& Status of ARV Therapy & & & \\
& Status of Anemia & 1 & & \\
& $\quad$ No Anemia & 1.294 & $0.561-2.983$ & 0.546 \\
& Mild & 0.959 & $0.392-2.345$ & 0.927 \\
& $\quad$ Medium & 1.142 & $0.401-3.250$ & 0.804 \\
& $\quad$ Severe & 1.806 & $1.230-2.652$ & 0.003 \\
& Total of CD4 & 4.043 & $1.232-13.270$ & 0.021 \\
\hline Clinical Stadium & 2.129 & $1.121-4.043$ & 0.021 \\
& Status of ARV & 1.853 & $1.280-2.683$ & 0.001 \\
& Total of CD4 & 4.206 & $1.289-13.728$ & 0.017 \\
\hline
\end{tabular}

Source: Own Study.

Based on Table 5, it can be seen that after implementing multivariate analysis on 5 variables, only 3 variables that have big influence against YPLL, those are; status of ARV therapy, total of CD4 and clinical stadium with p-value $<0.05$. 
Variable with the biggest influence on YPLL in RSUP Dr. M. Djamil Padang was clinical stadium $(\mathrm{OR}=4.20 ; \mathrm{p}=0.0017)$ and followed by status of $\mathrm{ARV}(\mathrm{OR}=2.13 ; \mathrm{p}=0.021)$ and total of CD4 $(\mathrm{OR}=1.85 ; \mathrm{p}=0.001)$.

\section{Discussion}

The observation result showed that the average age that confirmed positive in HIV was dominated with younger age around 30 years old as well as the dead age for around 26.09 years old. The fact that there were many patients who did not do the ARV therapy during their care in RSUP Dr. M. Djamil Padang (62.37\%) made them late to recognize the HIV status. Then, the condition became worst with the clinical condition, such as anemia (73.12\%), total of low CD4 $<200$ cell $/ \mathrm{mm}^{3}(62.36 \%)$, opportunistic infection $(56.99 \%)$ and severe clinical stadium.

The punctuality of HIV diagnosis affect the YPLL. The delay in diagnosis made people with HIV/AIDS lose two years of his life potential (Karnite, Brigis, \& Uuskula, 2013). The implication from this result is to optimize the promotive and preventive effort of HIV/AIDS, especially in case finding when patient is still in good clinical condition or in mild clinical stadium (early diagnosis).

The loss of potential years in HIV/AIDS patients in RSUP Dr. M. Djamil Padang is in accordance with Rumisha's study in Tanzania that found the average YPLL for 26 years. Meanwhile, Karnite reported the average YPLL in Latvia for 28.8 years (Karnite et al., 2013; Rumisha et al., 2020). Andarwatolanrain also found that there is meaningful relation between diagnosis age and the average years of YPLL, the lower the diagnosis age the bigger the YPLL (Andarwatolanrain, 2016).

This study found that there was meaningful relation between marital status and the average years of YPLL. Married person is more stable in sexuality rather than the unmarried person. The unmarried person tend to have sexual pair with more risk in transmitting some diseases (Kposowa, 2000).

The average years of YPLL also had significance relationship with the status of ARV therapy. Patients with HIV who follow the ARV therapy since the early stage have smaller progressivity to have AIDS or premature death (Zolopa et al., 2009). Baranov et al. (2015), in their study, claimed that in Sub-Sahara Africa the availability of ARV therapy was proved in lengthen life, reduce HIV transmission, enhance work productivity, decrease risk of death and improve mental health (Baranov, Bennett, \& Kohler, 2015). 
Some other studies reported on the success of ARV therapy in decreasing the number of death and prevent the appearance of opportunistic infection. While for the relation between risk of transmission factor and the average years of YPLL showed no connection. As Karnite et al. (2013) stated that there was significant differentiation between the average years of YPLL in IDU and non-IDU.

Wood et al., (2006) also found that the HIV patients who infected through IDU had more chance to death than the non IDU. It happened since the proportion of HIV patients and the risk of transmission factor through IDU was very little. In contrast, another study showed a high number of HIV patients who transmitted through IDU

This study also found that women YPLL was higher than men. As supported by Andarwatolanrain (2016) that the potential life lost in men is lower than women. However, Karnite et al. (2013) reported the opposite way, she found that the average years of YPLL for men in Lativa is higher than women, even if no significant relationship.

Another finding showed that there was significant differentiation between the total of CD4 in early diagnosis and the average years of YPLL. Sumantri also claimed that between the total of CD4 and the number of death risk there was significant relationship (Sumantri, Supandiman, Indjradinata, \& Ven A Van Der, 2008). Anggraeni (2010) added that the highest death incident rate happened in AIDS patients with total of CD4 $<50 \mathrm{cell} / \mathrm{mm}^{3}$ for $8 / 10.000$ people in a day. This was supported by Mugusi et al. (2009) and Schmaltz et al. (2012) that the total of CD4 $>100$ cell/ $/ \mathrm{mm}^{3}$ influence the lower mortality of HIV/AIDS patients, thus they did not lose many potential years in their lives.

\section{Conclusion}

Therefore, in conclusion, the average YPLL in HIV/AIDS patients in West Sumatera is categorized as quite high. Patients who confirmed positive was dominated by men with married status and worked as entrepreneur. Variable with the biggest influence was Clinical Stadium $(\mathrm{OR}=4.20 ; \mathrm{p}=0.0017)$ followed by the status of ARV $(\mathrm{OR}=2.13 ; \mathrm{p}=0.021)$ and total of CD4 (OR=1.85; $\mathrm{p}=0.001)$.

It is hoped for Health Office to give education on HIV/AIDS whether to the risky group or public society. Also, to enhance the awareness of HIV patients, it is suggested to follow the ARV therapy in routine and have healthy lifestyle due to increase the body immune before getting severe clinical condition which may cause death. 


\section{References}

Andarwatolanrain, A. N. (2016). Years of Potential Life Lost due to HIV-AIDS Infection and Associated Factors in Yogyakarta. Berita Kedokteran Masyarakat, 32, 5-10.

Anggraeni, N. D. (2010). Ketahanan Hidup Satu Tahun Pasien HIV-AIDS dengan Pengobatan Regimen ARV Lini Pertama Berdasarkan Jumlah CD4 Sebelum Pengobatan ARV di RSPI Prof.Dr.Sulianti Saroso Tahun 2005-2010. Jakarta.

Baranov, V., Bennett, D., \& Kohler, H. P. (2015). The indirect impact of antiretroviral therapy: Mortality risk, mental health, and HIV-negative labor supply. Journal of Health Economics, 44, 195-211. Retrieved from https://linkinghub.elsevier.com/retrieve/pii/S0167629615000831

Dinas Kesehatan Kota Padang. (2019). Laporan Tahunan Tahun 2018. Padang.

Gardner, J. W., \& Sanborn, J. S. (1990). Years of potential life lost (YPLL)--what does it measure? Epidemiology, 1(4), 322-329.

Karnite, A., Brigis, G., \& Uuskula, A. (2013). Years of potential life lost due to HIV infection and associated factors based on national HIV surveillance data in Latvia, 1991-2010. Scandinavian Journal of Infectious Diseases, 45(2). Retrieved from http://www.tandfonline.com/doi/full/10.3109/00365548.2012.717710

Kementerian Kesehatan RI. (2017). Situasi Umum HIV/AIDS dan Tes HIV. Jakarta.

Kposowa, A. J. (2000). Marital status and suicide in the National Longitudinal Mortality Study. Journal of Epidemiology and Community Health, 54(4), 254-261. Retrieved from https://pubmed.ncbi.nlm.nih.gov/10827907

Mc Donnell, S., Vossberg, K., Hopkins, R. S., \& Mittan, B. (1998). Using YPLL in Health Planning. Public Health Reports, 113(1), 55-61. Retrieved from https://pubmed.ncbi.nlm.nih.gov/9885530 
Mugusi, F. M., Mehta, S., Villamor, E., Urassa, W., Saathoff, E., \& Bosch, R. J. (2009). Factors associated with mortality in HIV-infected and uninfected patients with pulmonary tuberculosis. BMC Public Heath, 9.

Murray, C. J. L., Salomon, J. A., Mathers, C. D., Maas, P. J. Van Der, Lopez, A. D., \& Richardson, J. (2002). Summary Measures of Population Health: Concepts, Ethics, Measurement and Applications. Geneva: World Health Organization.

Rumisha, S. F., George, J., Bwana, V. M., \& Mboera, L. E. G. (2020). Years of Potential Life Lost and Productivity Costs Due to Premature Mortality From Six Priority Diseases in Tanzania, 2006-2015. PLoS One, 15(6). Retrieved from https://pubmed.ncbi.nlm.nih.gov/32516340

Schmaltz, C. A. S., Santoro-Lopes, G., Lourenco, M. C., Morgado, M. G., Velasque, L. D. S., \& Rolla, V. C. (2012). Factors impacting early mortality in tuberculosis/HIV patients: differences between subjects naïve to and previously started on HAART. PLoS One, 7(9).

Sugiyono, P. D. (2010). Metode penelitian pendidikan. Pendekatan Kuantitatif.

Sumantri, R., Supandiman, I., Indjradinata, P., \& Ven A Van Der, V. (2008). Immune Deficiency Syndrome berdasarkan Gabungan Derajat Anemia , Indeks Massa Tubuh , dan Jumlah Cluster. Bod, 44(1).

UNAIDS. (2020). Global HIV \& AIDS Statistics - 2020 Fact Sheet. Retrieved from UNAIDS website: https://www.unaids.org/en/resources/fact-sheet

Wood, E., Hoqq, R., Yip, B., Moore, D., Harrigan, P., \& Montaner, J. (2006). Impact of Baseline Viral Load and Adherence on Survival of HIV-Infected Adults with Baseline CD4 Cell Counts $>$ or $=200$ cells/microl. PubMed, 20(8), 1117-1123.

Zolopa, A. R., Andersen, J., Komarow, L., Sanne, I., Sanchez, A., \& Hogg, E. (2009). Early Antiretroviral Therapy Reduces AIDS Progression/Death in Individuals with Acute Opportunistic Infections: A Multicenter Randomized Strategy Trial. PLoS ONE, 4(5). 
Research, Society and Development, v. 9, n. 11, e88491110742, 2020

(CC BY 4.0) | ISSN 2525-3409 | DOI: http://dx.doi.org/10.33448/rsd-v9i11.10742

Percentage of contribution of each author in the manuscript

Radian Ilmaskal - 45\%

Gusni Rahma - 30\%

Edo Gusdiansyah $-25 \%$ 